\title{
Expression of the gene encoding the matrix gla protein by mature osteoblasts in human fracture non-unions
}

\author{
D M Lawton, J G Andrew, D R Marsh, J A Hoyland, A J Freemont
}

\begin{abstract}
Background-Osteoblast phenotypic abnormality, namely the expression of collagen type III, has been shown previously in fracture non-union woven bone.

Aims-To investigate osteoblasts from fracture non-unions for evidence of gene expression of non-collagenous bone matrix proteins that have been implicated in mineralisation, namely matrix gla protein (MGP), osteonectin, osteopontin, and osteocalcin. MGP is a consistent component of bone matrix, but there are no reports of osteoblasts in the skeleton expressing the gene for MGP, and the site of synthesis of skeletal MGP (perhaps the liver) has yet to be determined.
\end{abstract}

Methods-Biopsies from normally healing human fractures and non-unions were examined by means of in situ hybridisation, using ${ }^{35} \mathrm{~S}$ labelled probes and autoradiography to disclose levels of gene expression.

Results-In normally healing fractures, mature osteoblasts on woven bone were negative for MGP mRNA, but positive for osteonectin, osteopontin, and osteocalcin mRNA molecules. In non-unions, osteoblasts displayed a novel phenotype: they were positive for MGP $\mathrm{mRNA}$, in addition to osteonectin, osteopontin, and osteocalcin mRNA molecules.

Conclusions-Mature osteoblasts in slowly healing fractures have an unusual phenotype: they express the gene encoding MGP, which indicates that control of osteoblast gene expression in non-unions is likely to be abnormal. This might be of importance in the pathogenesis of nonuniting human fractures, and is of current interest given the emerging status of MGP as an inhibitor of mineralisation.

(F Clin Pathol: Mol Pathol 1999;52:92-96)

Keywords: fracture non-union; osteoblast; woven bone; in situ hybridisation; matrix gla protein; osteonectin; osteopontin

Several non-collagenous bone matrix proteins, including matrix gla protein (MGP), osteonectin/SPARC, osteopontin (formerly SPP1), and osteocalcin (formerly BGP (bone gla protein)) are found in large quantities in bone. They are thought to play a variety of important roles in bone development, growth, and turnover and are also thought to be involved in fracture repair. Osteocalcin appears to be unique to bone and dentine, and has been used widely as a marker of bony tissue development. Osteonectin, osteopontin (both functional members of the thrombospondin family), and osteocalcin appear to have roles in mineralisation; in addition, osteopontin and osteocalcin seem to have functions in resorption. ${ }^{12}$ During skeletogenesis, expression of the gene encoding MGP (a protein originally described in bone matrix) has been used as a reliable marker of the chondrogenic lineage, ${ }^{3-5}$ with osteoblasts appearing uniformly negative.

In the process of fracture healing, the evidence published to date on non-collagenous bone matrix proteins is solely from an animal model using the rat femur. ${ }^{6-8}$ Although this system has been used widely as a model of human fracture healing, there are some differences: cartilage production in human fracture callus appears to be less exuberant, and the process of callus mineralisation appears to take place later in humans than in the rat. The importance of open epiphyses in the adult rat to chondrocyte behaviour in this model is unclear, but fracture repair in children (who have open epiphyses) exhibits clear differences from the process in adults. We studied the expression of the genes encoding MGP, osteonectin, osteopontin, and osteocalcin to determine whether woven bone development in normally healing human fractures is similar to that described in the rat, and whether differences existed in fracture nonunions compared with normally healing bone.

\section{Materials and methods}

TISSUE PREPARATION

Specimens of human fracture callus from normally healing fractures were taken when available from the fracture sites of 15 closed fractures during surgery carried out to treat malreduction that had developed during conservative treatment. Biopsies were obtained between one and four weeks after fracture. Patients were aged between 18 and 87 years and were otherwise fit. On subsequent follow up, to one year, all these fractures, classed as normally healing, were found to have united normally. Abnormally healing fracture callus from non-unions was taken from the fracture site of 12 patients with extra-articular ununited fractures between four and 48 months after fracture.

The biopsy specimens were fixed in $10 \%$ neutral buffered formalin, decalcified in $20 \%$ EDTA ( $\mathrm{pH} 7.2)$ until decalcification was radiologically complete, embedded in paraffin wax, and sectioned at $7 \mu \mathrm{m}$. 
IN SITU HYBRIDISATION (ISH)

The probes used for ISH analysis of human osteonectin, osteopontin, and MGP were obtained from the American Type Culture Collection (ATCC), and that for osteocalcin
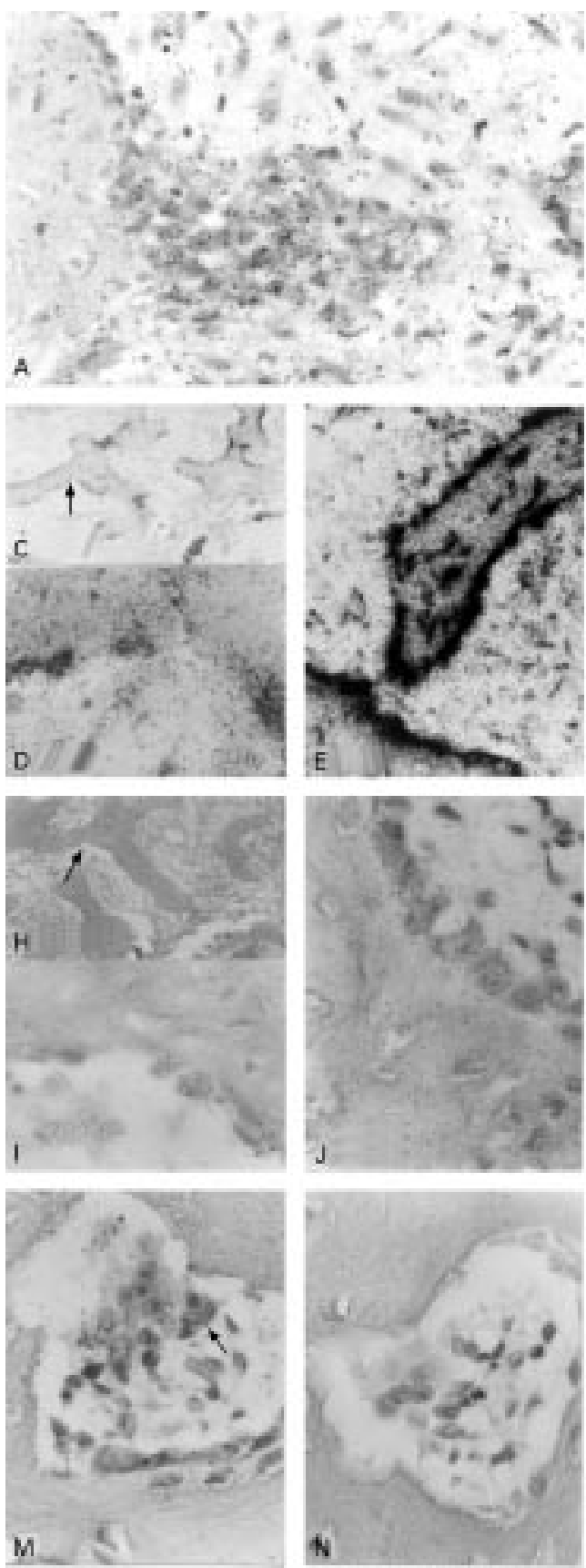

was obtained from Dr PJ Barr (Chiron Corporation, Emeryville, California, USA). Details of these primers are as follows: osteonectin, clone $\mathrm{HHCH} 67$, restriction digest insert ECORI $1.2 \mathrm{~kb}^{9}{ }^{10}$; osteopontin, clone Op-30, $1.4 \mathrm{~kb}^{11}$;
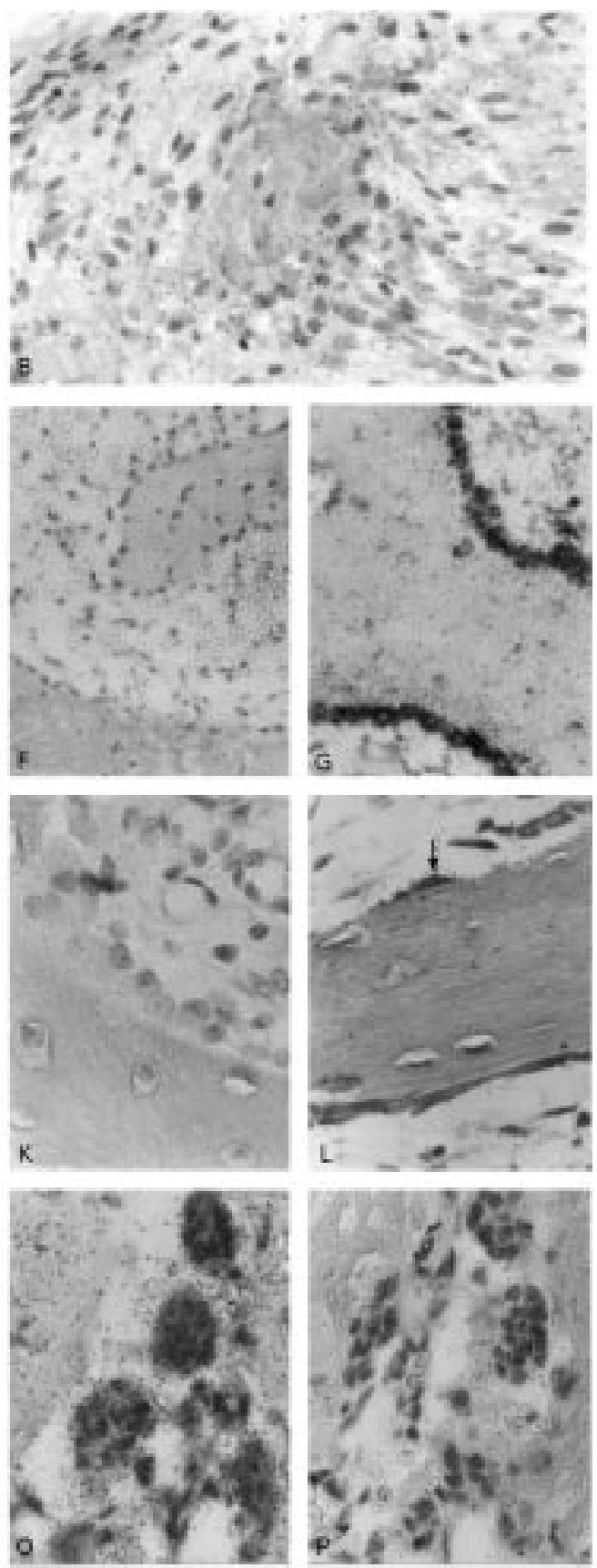

Figure 1 In situ hybridisation (ISH) for matrix gla protein (MGP), osteonectin, osteopontin, and osteocalcin in human fracture callus; haematoxylin and eosin stained. Sections $(A)$ and $(B)$ are from a non-union fracture; sections $(C-P)$ are from normally healing fractures. (A) MGP and (B) control (RNAase): osteoblasts on woven bone surfaces in non-unions were positive for MGP $m R N A$ signal; test and control are from the same area of the same specimen block. Sections (C-G) ISH for osteonectin. (C) In early woven bone osteoblasts were strongly positive for osteonectin $m R N A$ signal; the area selected in (D) shows the area indicated in $C$ (arrow) at a higher magnification; $(E)$ osteonectin and $(F)$ control

(RNAase) in early woven bone: non-cuboidal osteoblasts on the surface of woven bone, and many included osteoblasts, were positive for osteonectin $m R N A$ signal; $(G)$ osteonectin in woven bone: plump osteoblasts on the surface of woven bone were positive for osteonectin $m R N A$ signal. Sections $(H-N)$ ISH for osteopontin. (H) In early woven bone osteoblasts were weakly positive for osteopontin $m R N A$ signal, in contrast to a strong osteonectin $m R N A$ signal in the same area (C and $D)$; the area selected in (I) shows the area indicated in $H$ (arrow) at a higher magnification; (F) osteopontin and (K) control (RNAase) in woven bone: plump cuboidal osteoblasts on woven bone were positive for osteopontin $m R N A$ signal, whereas included osteoblasts were negative; $(L)$ osteopontin in lamellar bone: most flattened cells on the surface of lamellar bone were negative for osteopontin $m R N A$ signal, but occasional, scattered cells (about $10 \%$ of the total) were positive (arrow); (M) osteopontin and (N) control (RNAase): multinucleate osteoclast-like cells were positive for osteopontin $m R N A$ signal (arrow). Section (O) ISH for osteocalcin and (P) control (RNAase): multinucleate osteoclast-like cells were positive for osteocalcin $m R N A$ signal, to our knowledge a new finding for this cell type. 
Table 1 Human: non-collagenous bone matrix protein gene expression in normally healing fractures and non-unions

\begin{tabular}{|c|c|c|c|c|}
\hline & $M G P$ & Osteonectin & Osteopontin & Osteocalcin \\
\hline \multicolumn{5}{|l|}{ Haematoma } \\
\hline Macrophages, & - & + & + & - \\
\hline Polymorphs & _ & - & - & _- \\
\hline Granulation tissue mesenchyme & - & + & + & + \\
\hline Woven bone osteoblasts & $\begin{array}{l}- \\
+ \text { Only in } \\
\text { non-unions }\end{array}$ & + & $\begin{array}{l}\text { Early +/- } \\
\text { Later + }\end{array}$ & + \\
\hline Lamellar bone flat lining cells & - & $+/-$ & $\begin{array}{l}+10 \% \text {, scattered } \\
\text { individuals }\end{array}$ & $+/-$ \\
\hline Multinucleate resorptive cells & - & - & + & + \\
\hline Endothelial cells & - & - & - & - \\
\hline
\end{tabular}

MGP, clone hmGLA-19, ECORI insert $700 \mathrm{bp}^{12}$; osteocalcin, clone hBGP-1, $455 \mathrm{bp}$, containing a 300 nucleotide (19-318) open reading frame encoding a 100 amino acid human BGP precursor. ${ }^{13}$

PROBE PREPARATION AND HYBRIDISATION

All probes were random prime labelled using the Megaprime labelling system (Amersham, Little Chalfont, UK) to specific activities of $\sim 1 \times 10^{8}$ counts $/ \mathrm{min} / \mu \mathrm{g}$ using [35S]- $\alpha \mathrm{dCTP}$.

The ISH method has been described previously. ${ }^{14-18}$ Briefly, dewaxed sections were rehydrated, pretreated with proteinase $\mathrm{K}$, dehydrated, and air dried; RNAase negative controls were used. Sections were prehybridised for one hour at $37^{\circ} \mathrm{C}$ in $50 \%$ formamide, $1 \mathrm{mg} / \mathrm{ml}$ bovine serum albumin, $0.02 \%$ (wt/ vol) Ficoll, $0.02 \%$ (wt/vol) polyvinyl pyrrolidone, $0.6 \mathrm{M} \mathrm{NaCl}, 0.2 \mathrm{mg} / \mathrm{ml}$ sheared

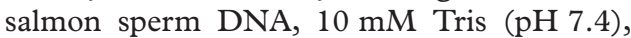
$0.5 \mathrm{mM}$ EDTA, $10 \mathrm{mM}$ dithiothreitol (DTT), and $10 \%$ (wt/vol) dextran sulphate. Hybridisation with heat denatured ${ }^{35} \mathrm{~S}$ labelled probe (100 $\mathrm{ng} / \mathrm{ml}$ prehybridisation mixture) was carried out at $37^{\circ} \mathrm{C}$ for 16 hours in prehybridisation solution. Aliquots of $50 \mu \mathrm{l}$ were applied to each slide and covered with siliconised coverslips. After hybridisation, the tissue sections were washed with a series of high stringency washes: twice for five minutes in $0.5 \times$ saline sodium citrate (SSC) with $1 \mathrm{mM}$ EDTA and $10 \mathrm{mM}$ DTT; twice for five minutes in $0.5 \times$ SSC with $1 \mathrm{mM}$ EDTA; four times for five minutes in $0.5 \times$ SSC at a temperature less than the melting temperature $\left(\mathrm{T}_{\mathrm{m}}\right.$ minus $\left.10^{\circ} \mathrm{C}\right)$ for each probe, followed by five minutes at room temperature in $0.5 \times$ SSC. Sections were then dehydrated and air dried. Autoradiography was performed with $\mathrm{K} 5$ emulsion (Ilford, Mobberly, UK), the slides being exposed at $4^{\circ} \mathrm{C}$ for 10-14 days and then developed in Kodak D-19 developer (Kodak, Paris, France) and counterstained with haematoxylin and eosin.
On microscopy, cells were categorised as chondrocytes, osteoblasts, and so on, in terms of their morphology and relation with their extracellular matrix; that is, the presence of lacunae, capsule/pericellular matrix, processes, and location on the surface of bone trabeculae.

\section{Results}

Human fracture callus has a heterogeneous appearance at histological examination, with several of the elements of normal fracture healing being present in close proximity in any one section. These elements include haematoma, fibrous tissue, woven and compact lamellar bone, and cartilage. Because of this heterogeneous appearance, callus specimens were graded 1-3 according to the predominant appearance of the callus, and cellular events were related to the histological grade, as follows: grade 1, fracture blood clot (haematoma) and granulation tissue; grade 2, definitive matrix formation without remodelling of cartilage (grade 2a) and/or bone (grade $2 \mathrm{~b}$ ); grade 3 , matrix remodelling. Within the non-union gap, tissues consisted largely of vascularised fibrous tissue or avascular cartilage.

\section{EXPRESSION OF GENES ENCODING}

NON-COLLAGENOUS BONE MATRIX PROTEINS Non-unions: $M G P$

A population of osteoblasts in non-unions on the surface of woven bone was positive for MGP mRNA signal (fig $1 \mathrm{~A}$ and $\mathrm{B}$ ); these were in the zone of new bone formation and in the interface zone. Osteoblasts in the old bone zone were almost always negative, whereas the gap zone rarely contained osteoblasts. Small and large chondrocytes were negative.

\section{Normal fractures: $M G P$}

Signal for MGP mRNA was characteristic of small and large chondrocytes in normal fractures but was never detected over osteoblasts at any location.

\section{Osteonectin, osteopontin, and osteocalcin in normal fractures and non-unions} Scattered macrophages and polymorphs in the haematoma were positive for osteonectin and osteopontin. In the granulation tissue, certain fibrous cells were positive for osteocalcin. (Tissue from these early stages of repair was only available from human fractures that were healing normally; these positive cell types have not been described previously in an animal model of normal fracture healing. ${ }^{7}$ ) On early woven bone, non-cuboidal osteoblasts were strongly positive

Table 2 Rat: non-collagenous bone matrix protein gene expression in normally healing fracture callus ${ }^{7}$

\begin{tabular}{|c|c|c|c|c|}
\hline & $M G P$ & Osteonectin & Osteopontin & Osteocalcin \\
\hline Day 1 & - & Proliferating periosteum & - & - \\
\hline Day 3 & - & Osteoblasts on woven bone & Osteoblasts on woven bone & Osteoblasts on woven bone \\
\hline Day 5 & Immature chondrocytes & Immature chondrocytes & & \\
\hline Day 7 & & $\begin{array}{l}\text { Osteoblastic cells on bone } \\
\text { trabeculae (endosteal) }\end{array}$ & $\begin{array}{l}\text { Osteoblastic cells on bone } \\
\text { trabeculae (endosteal) }\end{array}$ & $\begin{array}{l}\text { Osteoblastic cells on bone } \\
\text { trabeculae (endosteal) }\end{array}$ \\
\hline Day 14 & $\begin{array}{l}\text { Hypertrophic chondrocytes } \\
\text { (periosteal) }\end{array}$ & $\begin{array}{l}\text { Osteoblastic cells on bone } \\
\text { trabeculae (endosteal) }\end{array}$ & $\begin{array}{l}\text { Osteoblastic cells on bone } \\
\text { trabeculae (endosteal) } \\
\text { Hypertrophic chondrocytes } \\
\text { (periosteal) }\end{array}$ & $\begin{array}{l}\text { Osteoblastic cells on bone } \\
\text { trabeculae (endosteal) }\end{array}$ \\
\hline
\end{tabular}


for osteonectin mRNA signal, and included osteoblasts were equally positive (fig $1 \mathrm{C}-\mathrm{F}$ ). In later woven bone, cuboidal osteoblasts were strongly positive for osteonectin mRNA signal, but included osteoblasts were only weakly positive (fig 1G). Non-cuboidal osteoblasts on early woven bone were weakly positive for osteopontin mRNA signal (fig $1 \mathrm{H}$ and I). Later in repair, cuboidal osteoblasts on the surface of woven bone were moderately positive for osteopontin mRNA signal (fig $1 \mathrm{~J}$ and $\mathrm{K}$ ). In contrast to these levels of signal for osteopontin mRNA in the weak to medium range for osteoblasts, a strong signal for osteopontin mRNA was consistent over multinucleate resorptive cells (fig $1 \mathrm{M}$ and $\mathrm{N}$ ). Most flattened cells on the surface of lamellar bone were negative for osteopontin mRNA signal but occasional, scattered cells (about 10\% of the total) were positive (fig 1L). Flattened lining cells on lamellar bone were weakly positive for osteonectin and osteocalcin mRNA signals. Multinucleate resorptive cells, in addition to being positive for osteopontin mRNA signal, were also positive for osteocalcin mRNA signal (fig $1 \mathrm{M}$ and $\mathrm{O}$ ), but were negative for osteonectin mRNA signal. Endothelial cells were consistently negative for all non-collagenous bone matrix protein mRNA signals. Tables 1 and $2^{7}$ summarise the results.

\section{Discussion}

Various roles have been proposed for the noncollagenous bone matrix proteins, namely MGP, osteonectin, osteopontin, and osteocalcin, in a number of processes including mineralisation, bone resorption, and cell attachment to extracellular matrix. ${ }^{19-23}$ On the basis of findings in MGP deficient mice of inappropriate growth plate calcification, short status, osteopaenia, and fractures, it appears that MGP may be an inhibitor of mineralisation. ${ }^{5}$ Our study examined expression of the genes encoding MGP, osteonectin, osteopontin, and osteocalcin in human fracture healing, a situation of rapid elaboration of intramembranous and endochondral bony matrix. Gene expression of these molecules during the process of fracture healing has been investigated previously in a rat model of normal fracture healing (osteonectin and osteocalcin by means of northern blotting ${ }^{6}$; osteocalcin by means of $\mathrm{ISH}^{8}$; and MGP, osteonectin, osteopontin, and osteocalcin by means of ISH. ${ }^{7}$ )

Our studies on fracture callus of normally healing fractures have shown an osteoblast phenotype that has not been reported previously in humans. The osteoblast phenotype in an animal model of normal fracture healing was MGP negative, but osteonectin, osteopontin, and osteocalcin positive (table 2 ). ${ }^{7}$ Normal fracture healing in humans is consistent with these findings, except for low levels of osteopontin gene expression (compare with osteoclasts $^{24}$; fig 1I, J, and M), which might be related to the slower healing rates seen in humans compared with the rat. Also notable was osteopontin gene expression by occasional, scattered, flattened lining osteoblasts (fig 1L), in contrast to relative inactivity of the residual population; this may relate to a signalling role for osteopontin. ${ }^{25}$

In non-unions, the osteoblast phenotype was different. In particular, osteoblasts on woven bone expressed the gene for MGP. Expression of this gene, characteristic of chondrogenic tissues during skeletogenesis, has previously been reported in cultured osteoblasts ${ }^{26-31}$ but, to our knowledge, not in osteoblasts in skeletal samples. ${ }^{45}$ Expression of the MGP and collagen type $\mathrm{III}^{18}$ genes by osteoblasts in biopsies of non-unions raises fundamental questions about control mechanisms operating in osteoblasts, and could have important implications for understanding mechanisms leading to fracture non-union.

This work was funded by the Medical Research Council. The osteocalcin cDNA probe was kindly donated by Dr PJ Barr. Presented in part at the Bone and Tooth Society, UK, and at the University of Seattle Conference, The thrombospondin gene family and its functional relatives, tenascins, osteopontin, and SPARC, June 1996.

1 Roach HI. Why does bone matrix contain non-collagenous proteins? The possible roles of osteocalcin, osteonectin, osteopontin and bone sialoprotein in bone mineralisation and resorption. Cell Biology International Reports 1994;18:617-27.

2 Dodds RA, Connor JR, James IE, et al. Human osteoclasts, not osteoblasts, deposit osteopontin onto resorption surfaces: an in vitro and ex vivo study of remodeling bone. f Bone Miner Res 1995;10:1666-80.

3 Rice JS, Williamson MK, Price PA. Isolation and sequence of the vitamin K-dependent matrix Gla protein from the calcified cartilage of the soupfin shark. $\mathcal{F}$ Bone Miner Res 1994;9:567-76

4 Luo G, D'Souza R, Hogue D, et al. The matrix Gla protein gene is a marker of the chondrogenesis cell lineage during mouse development. F Bone Miner Res 1995;10:325-34.

5 Luo G, Ducy P, McKee MD, et al. Spontaneous calcification of arteries and cartilage in mice lacking matrix GLA protein. Nature 1997;358:78-81.

6 Jingushi S, Joyce ME, Bolander ME. Genetic expression of extracellular matrix proteins correlates with histologic extracellular matrix proteins correlates with histologic
changes during fracture repair. $\mathcal{F}$ Bone Miner Res 1992;7: changes duri

7 Hirakawa K, Hirota S, Ikeda T, et al. Localization of the mRNA for bone matrix proteins during fracture healing as determined by in situ hybridization. $\mathcal{F}$ Bone Miner Res 1994;9:1551-7.

8 Hughes SS, Hicks DG, O'Keefe RJ, et al. Shared phenotypic expression of osteoblasts and chondrocytes in fracture callus. $\mathcal{F}$ Bone Miner Res 1995;10:533-44.

9 Adams MD, Kelley JM, Gocayne JD, et al. Complementary DNA sequencing: expressed sequence tags and human genome project. Science 1991;252:1651-6.

10 Polymeropoulos MH, Xiao H, Sikela JM, et al. Chromosomal distribution of 320 genes from a brain cDNA library. Nat Genet 1993;4:381-6.

11 Kiefer MC, Bauer DM, Barr PJ. The cDNA and derived Kiefer MC, Bauer DM, Barr PJ. The cDNA and derived
amino acid sequence for human osteopontin. Nucleic Acids Res 1989;17:3306.

12 Kiefer MC, Bauer DM, Young D, et al. The cDNA and derived amino acid sequences for human and bovine matrix Gla protein. Nucleic Acids Res 1988;16:5213

13 Kiefer MC, Saphire AC, Bauer DM, et al. The cDNA and derived amino acid sequences of human and bovine bone Gla protein. Nucleic Acids Res 1990;18:1909.

14 Hoyland JA, Thomas JT, Donn R, et al. Distribution of type $\mathrm{X}$ collagen mRNA in normal and osteoarthritic human cartilage. Bone and Mineral 1991;15:151-64.

15 Andrew JG, Hoyland JA, Andrew SM, et al. Demonstration of TGF- $\beta 1$ mRNA by in situ hybridization in normal human fracture healing. Calcif Tissue Int 1993;52:74-8.

16 Andrew JG, Hoyland JA, Freemont AJ, et al. Insulinlike growth factor gene expression in human fracture callus. growth factor gene expression in
Calcif Tissue Int 1993b;53:97-102.

17 Andrew JG, Hoyland JA, Freemont AJ, et al. Plateletderived growth factor expression in normally healing human fractures. Bone 1995;16:455-60.

18 Lawton DM, Andrew JG, Marsh DR, et al. Mature osteoblasts in human non-union fractures express collagen type III. F Clin Pathol: Mol Pathol 1997;50:194-7.

19 St-Arnaud R, Prud'homme J, Leung-Hagesteijn C, et al. Constitutive expression of calreticulin in osteoblasts inhibits mineralization. $\mathcal{F}$ Cell Biol 1995;131:1351-9.

20 Sohma Y, Suzuki T, Sasano H, et al. Expression of mRNA for matrix gamma-carboxyglutamic acid protein during progression of atherosclerosis in aortae of Watanabe heritable hyperlipidemic rabbits. F Biochem (Tokyo) 1994;116: 747-51.

21 Murphy-Ullrich JE, Lane TF, Pallero MA, et al. SPARC mediates focal adhesion disassembly in endothelial cells 
through a follistatin-like region and the $\mathrm{Ca}(2+)$-binding EF-hand. F Cell Biochem 1995;57:341-50.

22 Strandjord TP, Sage EH, Clark JG. SPARC participates in the branching morphogenesis of developing fetal rat lung. Am f Respir Cell Mol Biol 1995;13:279-87.

23 Xuan JW, Hota C, Shigeyama Y, et al. Site-directed mutagenesis of the arginine-glycine-aspartic acid sequence in osteopontin destroys cell adhesion and migration functions. F Cell Biochem 1995;57:680-90

24 Tezuka K, Sato T, Kamioka H, et al. Identification of osteopontin in isolated rabbit osteoclasts. Biochem Biophys Res Commun 1992;186:911-17.

25 Cantor $\mathrm{H}$. The role of Eta-1/osteopontin in the pathogenesis of immunological disorders. Ann N Y Acad Sci 1995;760: $143-50$.

26 Barone LM, Owen TA, Tassinari MS, et al. Developmental expression and hormonal regulation of the rat matrix Gla protein (MGP) gene in chondrogenesis and osteogenesis. $\mathcal{F}$ Cell Biochem 1991;46:351-65.

27 Owen TA, Aranow MS, Barone LM, et al. Pleiotropic effects of vitamin D on osteoblast gene expression are related to of vitamin $\mathrm{D}$ on osteoblast gene expression are related to
the proliferative and differentiated state of the bone cell phenotype: dependency upon basal levels of gene expression, duration of exposure, and bone matrix competency in normal rat osteoblast cultures. Endocrinology 1991;128: 1496-504.

28 Zhou H, Hammonds RG, Jr, Findlay DM, et al. Retinoic acid modulation of mRNA levels in malignant, nontransformed, and immortalized osteoblasts. $\mathcal{F}$ Bone $M$ 1991;6:767-77.

29 Choong PF, Martin TJ, Ng KW. Effects of ascorbic acid, calcitriol, and retinoic acid on the differentiation of preosteoblasts. F Orthop Res 1993;11:638-47.

30 Barone LM, Aronow MA, Tassinari MS, et al. Differential effects of warfarin on mRNA levels of developmentally regulated vitamin $\mathrm{K}$ dependent proteins, osteocalcin, and matrix GLA protein in vitro. 7 Cell Physiol 1994;160:25564 .

31 Asahina I, Sampath TK, Hauschka PV. Human osteogenic protein-1 induces chondroblastic, osteoblastic, and/or adipocytic differentiation of clonal murine target cells. Exp Cell Res 1996;222:38-47. 